\title{
PENGEMBANGAN MEDIA PEMBELAJARAN BERBASIS VIDEO TUTORIAL INTERAKTIF PADA MATA PELAJARAN TEKNIK ANIMASI 2 DIMENSI
}

\author{
Baiq Ade Irma Willi Yana ${ }^{1}$,Yosi Nur Kholisho' ${ }^{2}$, Ahmad Fathoni ${ }^{3}$ \\ ${ }^{1,2,3}$ Program Studi Pendidikan Informatika, \\ Fakultas Matematika dan Ilmu Pengetahuan Alam, Universitas Hamzanwadi \\ email: baiqade29@gmail.com ${ }^{1}$, yosink.peninfo@gmail.com ${ }^{2}$, \\ ahmad.fathonis2ptk@gmail.com ${ }^{3}$
}

\begin{abstract}
Abstrak
Penelitian ini bertujuan untuk: (1) mengembangkan media pembelajaran berbasis vidio tutorial interaktif pada mata pelajaran teknik animasi 2 dimensi dengan materi teknik animasi frame kelas XI Multimedia di SMK Negeri 1 Kopang (2) mengetahui kelayakan media pembelajaran berbasis video tutorial interaktif. Jenis penelitian ini adalah Research and Development (R\&D) dengan prosedur pengembangan: potensi dan masalah, pengumpulan data, desain produk, validasi desain, revisi desain, ujicoba produk, revisi produk, ujicoba pemakaian. Model pengembangan perangkat lunak yang digunakan model air terjun. Kelayakan media pembelajaran dinilai oleh ahli media, ahli materi dan pengguna. Instrumen pengumpulan data yakni dokumentasi dan kuesioner.Analisis data hasil uji kelayakan menggunakan skala Likert. Hasil penelitian: (1) media pembelajaran berbasis vidio tutorial interaktif yang dikembangkan berupa software dikemas dalam bentuk file .exe dan CD interaktif. (2) Media pembelajaran berbasis video tutorial layak digunakan dalam proses pembelajaran, berdasarkan hasil validasi dari ahli media memperoleh persentase sebesar $86,69 \%$, ahli materi sebesar $82,81 \%$, dan uji coba produk sebesar $75,93 \%$ dan uji coba pemakaian memperoleh persentase sebesar $79,89 \%$. Secara keseluruhan media pembelajaran berbasis video tutorial interaktif memperoleh persentase sebesar $76,66 \%$ dalam kategori kelayakan media "Sangat Layak".
\end{abstract}

Kata Kunci: Media Pembelajaran, Video Tutorial Interaktif

\begin{abstract}
This research aims to: (1) developing video-based learning media is an interactive tutorial on subjects of engineering animation 2 dimensions with frame animation technique material class XI Multimedia at SMK Negeri 1 Kopang (2) know the feasibility of media interactive video tutorialbased learning. This type of research is a Research and Development $(R \& D)$ and the development of procedures: potential and problems, data collection, product design, design validation, product test design, revision, revision products, free trial usage. The software development model used the waterfall model. The feasibility study is judged by media experts, media content and users. Data collection instruments namely documentation and questionnaires. Data analysis the results of the test the feasibility of using the Likert scale. Results of research: (1) media video-based learning, interactive tutorials that were developed in the form of software packaged in the form of an .exe file and interactive CD. (2) a Media-based learning video tutorials worth used in the learning process, based on the results of the validation of media experts earn a percentage of $86.69 \%$, expert of $82.81 \%$, material and product testing of $75.93 \%$ and trial usage earn a percentage of $79.89 \%$. Overall the media-based learning, interactive video tutorial earn a percentage of $76.66 \%$ eligibility category in the media "very decent".
\end{abstract}

Keywords: Learning media, Interactive Video tutorials. 


\section{PENDAHULUAN}

Perkembangan ilmu teknologi dan informasi saat ini, menyebabkan semakin berkembangnya dunia pendidikan di Indonesia. Pelaksanaan pendidikan di Indonesia senantiasa menghadirkan perubahan-perubahan dalam rangka penyempurnaan agar dapat sesuai dengan kebutuhan pembangunan suatu bangsa. Keberhasilan pendidikan dapat dicapai dengan mengoptimalkan komponen-komponen yang ada dalam sistem pendidikan salah satunya adalah media pembelajaran yang digunakan sebagai perantara dalam proses pembelajaran. Media pembelajaran dapat dikembangkan dengan memanfaatkan teknologi informasi dan komunikasi yang ada saat ini, seperti media pembelajaran berbasis multimedia, namun kenyataannya banyak sekolah yang kurang mengembangkan dan memanfaatkan media pembelajaran terutama media berbasis teknologi. Kurangnya variasi media pembelajaran dalam proses belajar mengajar berdampak pada tingkat pemahaman siswa terhadap suatu materi pelajaran. Ada sebagian siswa yang cepat memahami materi ada pula siswa yang lambat memahami materi pelajaran, karena tingkat pemahaman yang berbeda, sehingga menuntut guru atau pendidik lebih kreatif dalam menyampaikan materi pelajaran. Oleh karena itu media pembelajaran perlu dikembangkan dan diterapkan di sekolah.

Berdasarkan observasi yang telah dilakukan di SMK Negeri 1 Kopang, penggunaan media pembelajaran dalam proses belajar mengajar masih kurang. Banyak guru yang belum memanfaatkan teknologi yang tersedia untuk digunakan sebagai media pembelajaran. Guru masih terpaku pada metode ceramah dalam penyampaian materi, praktik dan demonstrasi. Sehingga siswa masih kesulitan memahami materi pelajaran, untuk mengatasi hal tersebut diperlukan media pembelajaran yang dapat membantu kelancaran dalam proses belajar mengajar agar guru tidak kesulitan menjelaskan materi pelajaran dan siswa lebih mudah menyerap materi pelajaran. Permasalahan ditemukan berdasarkan pengamatan yang dilakukan pada kegiatan belajar mengajar di laboratorium multimedia SMK Negeri 1 Kopang pada mata pelajaran teknik animasi 2 dimensi yakni kurangnya media pembelajaran yang digunakan dalam proses belajar mengajar. Kurangnya media pembelajaran tersebut mempengaruhi pemahaman siswa akan materi yang disampaikan.

Pemaparan permasalahan di atas dapat disimpulkan bahwa dalam proses belajar mengajar pada mata pelajaran teknik animasi 2 dimensi diperlukan adanya pengembangan media pembelajaran yang dapat membantu guru dan siswa. Diperlukan sebuah media pembelajaran yang mampu memberikan visualisasi yang baik, yang akan memunculkan semangat belajar, menarik minat siswa mempelajari suatu materi pelajaran dan meningkatkan penguasaan siswa terhadap materi yang disajikan sehingga berdampak pada peningkatan hasil belajar siswa. Media pembelajaran yang berbasis video tutorial interaktif sangat diperlukan dalam mata pelajaran teknik animasi 2 dimensi terutama pada materi teknik animasi frame.

Adanya pengembangan media pembelajaran berbasis vidio tutorial interaktif diharapkan dapat memenuhi kebutuhan siswa. Dengan kemasan dan penyajian yang menarik, dapat memunculkan semangat belajar, menarik minat, membantu siswa lebih memahami dan menguasai materi pelajaran dan meningkatkan hasil belajar. Media pembelajaran dapat digunakan langsung dalam proses belajar mengajar di kelas atau laboratorium dan dapat digunakan siswa sebagai pembelajaran secara mandiri. Dengan demikian dilakukan penelitian dengan judul "Pengembangan Media Pembelajaran Berbasis Video Tutorial Interaktif Pada Mata Pelajaran Teknik Animasi 2 Dimensi Kelas XI Multimedia Di SMK Negeri 1 Kopang”.

Peneliti Fathoni (2016), Dinata (2013), Efendi (2014) merupakan penelitian sejenis yang membahas pengembangan media pembelajaran berbasis video tutorial interaktif. Ketiga peneliti tersebut pada intinya menyimpulkan bahwa media pembelajaran berbasis video 
tutorial interaktif layak digunakan dalam proses pembelajaran dan memberikan efektifitas pada pembelajaran.

\section{METODE PENELITIAN}

Jenis Penelitian yang digunakan peneliti adalah Research and Development/R\&D Sugiyono (2014). Penelitian dan pengembangan yang dilakukan peneliti merupakan suatu proses yang digunakan untuk mengembangkan sebuah produk yang berupa media pembelajaran berbasis video tutorial interaktif yang digunakan dalam proses pembelajaran pada mata pelajaran teknik animasi 2 dimensi pokok bahasan yang difokuskan tenik animasi frame di SMK Negeri 1 Kopang pada kelas XI Multimedia.

Model pengembangan perangkat lunak yang digunakan dalam proses pengembangan media pembelajaran berbasis video tutorial interaktif yaitu model waterfall yang dapat dilihat pada gambar di bawah ini.

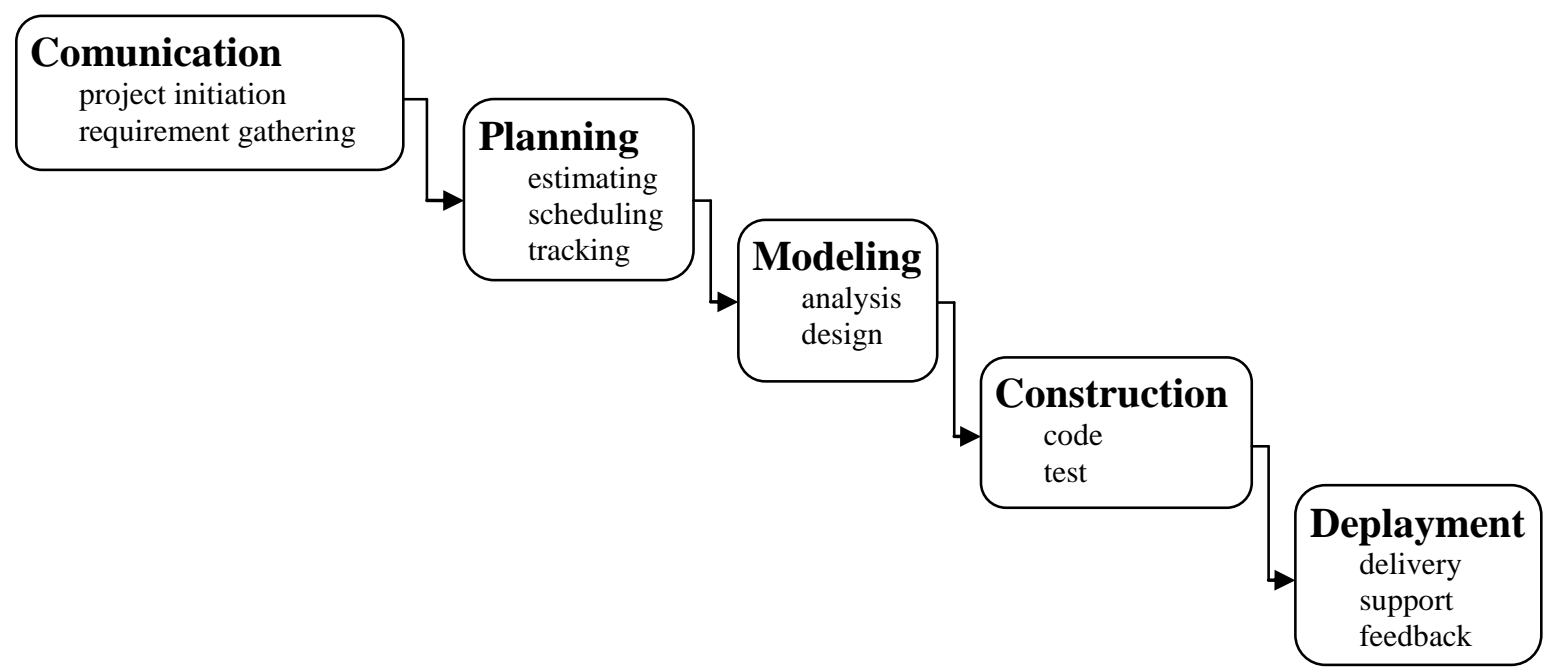

Gambar 1.Tahapan Model Waterfall (Pressman, 2015)

Berdasarkan gambar di atas berikut ini penjelasan tahapan model waterfall menurut Prassman (2015) diantaranya; (1) Communication: komunikasi kepada pengguna. langkah ini merupakan langkah penting karena menyangkut pengumpulan informasi tentang kebutuhan pengguna. Dalam penelitian dan pengembangan ini informasi kebutuhan pengguna diperoleh melalui wawancara, diskusi dan survei langsung dengan pengguna yaitu siswa kelas XI jurusan Multimedia di SMK Negeri 1 Kopang. Informasi yang didapatkan kemudian dianalisis untuk mendapatkan data yang dibutuhkan siswa; (2) Planning: menetapkan rencana untuk pengerjaan software sesuai dengan data yang diperoleh berdasarkan keinginan pengguna; (3) Modeling: proses ini menerjemahkan syarat ke sebuah perancangan software yang dapat diperkirakan sebelum membuat coding. Proses ini berfokus pada rencangan struktur data, arsitektur software, representasi interface, dan detail (algoritma) procedural; (3) Construction: merupakan proses membuat kode (code generation). Coding atau pengkodean merupakan penerjemahan desain dalam bahasa yang bisa dikenali oleh komputer. Programmer akan menerjemahkan keinginan yang diminta oleh pengguna. Tahapan inilah yang merupakan tahapan secara nyata dalam mengerjakan suatu software, artinya penggunaan komputer akan dimaksimalkan dalam tahapan ini. Setelah pengkodean selesai maka akan dilakukan testing terhadap sistem yang telah dibuat. Tujuan testing adalah menemukan kesalahan-kesalahan terhadap sistem tersebut untuk kemudian bisa diperbaiki; 
(4) Deployment: Tahapan ini bisa dikatakan final dalam pembuatan sebuah software atau sistem. Setelah melakukan analisis, desain dan pengkodean maka sistem yang sudah jadi akan digunakan pengguna.

Penelitian ini dilakukan di SMK Negeri 1 Kopang pada kelas XI Multimedia. Penelitian dilakukan secara bertahap dengan menyesuaikan jadwal pelajaran teknik animasi 2 dimensi. Subjek penelitian yakni 1 orang ahli materi, 2 orang ahli media untuk validasi media pembelajaran dan 10 orang siswa untuk uji coba produk dan 30 orang siswa untuk uji coba pemakaian.

Data yang diperoleh dalam penelitian ini berupa data deskriptif kuantitatif. Data kuantitatif diperoleh dari penilaian media pembelajaran berbasis video tutorial oleh ahli media dan ahli materi yang menunjukan kevalidan media pembelajaran dan respon siswa tehadap media pembelajaran. Untuk memperoleh data yang baik dalam sebuah penelitian dipengaruhi oleh cara memperoleh data dan harus mengikuti metode dan teknik yang sesuai dengan permasalahan penelitian yang dibahas.

Metode yang digunakan dalam pengumpulan data penelitian ini yakni; (a) metode dokumentasi, digunakan untuk mendapatkan informasi tentang peserta didik yang akan dijadikan subjek penelitian; (b) kuisioner (angket), digunakam untuk ahli media, ahli materi dan siswa dalam penelitian ini untuk mengukur kualitas media yang dikembangkan.

Instrumen angket pada penelitian ini digunakan untuk memperoleh data dari ahli media, ahli materi dan pengguna sebagai bahan mengevaluasi media pembelajaran yang dikembangkan. Instrumen kelayakan media pembelajaran pada penelitian ini menggunakan skala Likert dengan 4 alternatif jawaban yaitu Sangat Baik, Baik, Cukup dan Kurang. Angket untuk siswa dibuat guna mengetahui pendapat atau respon siswa.

\section{HASIL DAN PEMBAHASAN}

\section{Hasil pengembangan}

\section{Validasi Produk}

a. Data validasi ahli media: Validasi oleh ahli media dilakukan untuk menguji aspek usability, functionality dan aspek komunikasi visual. Pada tahap ini validasi pengujian media pembelajaran dilakukan oleh dua orang ahli media yang terdiri dari tenaga pengajar yang ahli dibidangnya. Validasi ahli media dilakukan menggunakan kuisioner dengan skala likert 1 sampai 4. Dari data yang telah didapatkan dari 2 ahli media kemudian, dilakukan analisis data. Berikut ini tabel 1. Hasil pengujian ahli media:

Tabel 1. Hasil Pengujian Ahli Media

\begin{tabular}{clcccc}
\hline No & Aspek Penilaian & $\begin{array}{c}\text { Jml } \\
\text { Butir }\end{array}$ & $\begin{array}{c}\text { Skor Ahli } \\
\text { Media }\end{array}$ & $\begin{array}{c}\text { Skor Yang } \\
\text { Diharapkan }\end{array}$ & $\begin{array}{c}\text { Persentase } \\
\text { Kelayakan }\end{array}$ \\
\hline 1 & Usability & 4 & 27 & 32 & $84,37 \%$ \\
2 & Funcionality & 13 & 96 & 104 & $92,30 \%$ \\
3 & Komunikasi visual & 14 & 92 & 112 & $92,14 \%$ \\
\hline$\quad$ Jumlah & 31 & 215 & 248 & \\
\hline & Skor rata-rata & & & & $86,69 \%$ \\
\hline
\end{tabular}

Berdasarkan tabel di atas dapat dijelaskan bahwa hasil penilaian ahli media terhadap aspek usability media pembelajaran berbasis video tutorial interaktif diperoleh persentase sebesar $84,37 \%$ berdasarkan skala persentase kelayakan termasuk dalam kategori sangat layak. Hasil penilaian ahli media terhadap terhadap 
aspek Funcionality pada media pembelajaran berbasis video tutorial interaktif memperoleh persentase $92,30 \%$. Berdasarkan skala persentase kelayakan termasuk dalam kategori sangat layak. Hasil penilaian ahli media terhadap terhadap aspek komunikasi visual pada media pembelajaran berbasis video tutorial interaktif memperoleh persentase $92,14 \%$. Berdasarkan skala persentase kelayakan termasuk dalam kategori sangat layak.

b. Data validasi ahli materi: Validasi ahli materi dilakukan untuk mengetahui kualitas media pembelajaran dari aspek desain pembelajaran, isi materi dan aspek bahasa dan komunikasi. Hasil pengujian ahli materi pada penelitian dan pengembangan ini dapat dilihat pada tabel 2 di bawah ini.

Tabel 2. Hasil Pengujian Ahli Materi

\begin{tabular}{clcccc}
\hline No & Aspek Penilaian & $\begin{array}{c}\text { Jml } \\
\text { Butir }\end{array}$ & $\begin{array}{c}\text { Skor Ahli } \\
\text { Materi }\end{array}$ & $\begin{array}{c}\text { Skor Yang } \\
\text { Diharapkan }\end{array}$ & $\begin{array}{c}\text { Persentase } \\
\text { Kelayakan }\end{array}$ \\
\hline 1 & Desain Pembelajaran & 6 & 19 & 24 & $79,16 \%$ \\
2 & Isi Materi & 6 & 20 & 24 & $83,33 \%$ \\
3 & Bahasa Dan & 4 & 14 & 16 & $87,50 \%$ \\
& Komunikasi & & & & \\
\hline \multicolumn{2}{r}{ Jumlah } & 16 & 53 & 64 & \\
\hline & Skor Rata-Rata & & & & $\mathbf{8 2 , 8 1 \%}$ \\
\hline
\end{tabular}

Berdasarkan tabel di atas dapat dijelaskan bahwa hasil penilaian ahli materi terhadap aspek desain pembelajaran diperoleh persentase sebesar 79,16\% berdasarkan skala persentase kelayakan termasuk dalam kategori "sangat layak". Hasil penilaian ahli materi terhadap terhadap aspek isi materi memperoleh persentase 83,33\%, berdasarkan skala persentase kelayakan termasuk dalam kategori "sangat layak". Hasil penilaian ahli materi terhadap terhadap aspek bahasa dan komunikasi memperoleh persentase $87,50 \%$, berdasarkan skala persentase kelayakan termasuk dalam kategori "sangat layak". Secara keseluruhan hasil penilaian ahli materi terhadap media pembelajaran berbasis video tutorial interaktif memperoleh persentase sebesar 82,81\%, berdasarkan kategori kelayakan media "Sangat Layak", sehingga layak digunakan sebagai media pembelajaran.

c. Data Uji Coba produk : Uji coba dilakukan untuk menguji kualitas media pembelajaran dari aspek usability. Uji coba produk dilakukan setelah produk direvisi dan dinyatakan layak oleh ahli media dan ahli materi. Pengambilan data pada uji coba produk menggunakan kuisioner. Hasil penilaian dari 10 siswa terhadap media pembelajaran berbasis video tutorial interaktif diperoleh skor 486 dengan skor harapan 640, sehingga memperoleh persentase 75,93\%, berdasarkan kategori kelayakan media "Layak", sehingga layak digunakan sebagai media pembelajaran.

d. Uji Coba Pemakaian: Uji coba pemakaian dilakukan untuk penerapan produk yang dikembangkan. Hasil penilaian dari 30 siswa terhadap media pembelajaran berbasis video tutorial interaktif dengan 16 butir pernyataan diperoleh skor 1534 dengan skor harapan 1920, sehingga memperoleh persentase 79,89\%. Berdasarkan kategori kelayakan media, maka media pembelajaran berbasis video tutorial interaktif dalam kriteria kelayakan "Sangat Layak", sehingga layak digunakan sebagai media pembelajaran.

Hasil pengembangan produk 
Hasil pengembangan produk berupa software media pembelajaran berbasis video tutorial interaktif untuk kelas XI Multimedia di SMK Negeri 1 kopang. Software media pembelajaran dikemas dalam file .exe (extensi) dan CD Interaktif.

\section{Pembahasan}

Pembahasan pada penelitian ini ditunjukkan pada permasalahan yang disebutkan dalam rumusan masalah. Permasalahan itu kemudian dibahas sesuai dengan hasil yang telah diperoleh selama penelitian. Metode penelitian ini mengacu pada prosedur penelitian dan pengembangan Sugiyono (2014). Beberapa tahapan yang dilakukan yaitu potensi dan masalah, pengumpulan data, desain produk, validasi desain, revisi desain, ujicoba produk dan ujicoba pemakaian. Model pengembangan perangkat lunak atau software media pembelajaran berbasis video tutorial interaktif digunakan model waterfall menurut Pressmen (2015). Tahapan model waterfall yakni communication, planning, modeling, contruction dan deployment.

Kelayakan media pembelajaran berdasarkan validasi dari ahli media dan ahli materi. Validasi ahli media melibatkan 2 orang ahli media. Ahli media menguji kualitas media pembelajaran dari aspek usability yakni penilaian media dari kemudahan penggunaan menu, ketepatan penempatan dan penggunaan tombol, aspek functionality yakni penggunaan tombol utama, menu utama, tombol dan menu soal latihan dan aspek komunikasi visual yakni penilaian media dari komunikasi, kualitas visual, penggunaan media bergerak (vidio, animasi), penggunaan audio, dan kesederhanaan dan kemenarikan. Hasil keseluruhan tiap aspek tersebut sebesar 86,69\% dalam kategori kelayakan media "Sangat Layak", sehingga layak digunakan sebagai media pembelajaran. Pada validasi ahli materi melibatkan 1 orang ahli materi. Ahli materi menguji kualitas media pembelajaran dari aspek desain pembelajaran yakni penilaian dari kejelasan tujuan, relevansi antar aspek pembelajaran (tujuan, materi, penggunaan media), isi materi yakni kualitas isi materi, aktualisasi materi, cakupan materi, kedalaman materi dan kesesuaian materi, aspek bahasa dan komunikasin yakni penilaian media pembelajaran dari kebenaran bahasa dan kesesuaian gaya bahasa. Hasil keseluruhan tiap aspek tersebut sebesar 82,81\% dalam kategori kelayakan media "Sangat Layak", sehingga layak digunakan sebagai media pembelajaran.

Tahap uji coba produk dilakukan untuk mengetahui respon siswa serta kelayakan media pembelajaran dilihat dari pengguna. Uji coba produk melibatkan 10 orang siswa, penilaian media pembelajaran berdasarkan aspek usability yakni usefulness (kegunaan), ease of use (mudah dalam penggunaan), ease of learning (mudah untuk dipelajari) dan satisfaction (kepuasan). Hasil uji coba produk pada siswa terhadap media pembelajaran berbasis video tutorial interaktif memperoleh persentase sebesar $75,93 \%$, berdasarkan skala persentase kelayakan, maka media pembelajaran berbasis video tutorial interaktif dalam kategori kelayakan media "Layak", sehingga layak digunakan sebagai media pembelajaran. Selanjutnya dilakukan ujicoba pemakaian yang melibatkan 30 siswa, hasil uji coba pemakaian memperoleh persentase $79,89 \%$. Berdasarkan kategori kelayakan media, maka media pembelajaran berbasis video tutorial interaktif dalam kategori kelayakan media "Sangat Layak", sehingga layak digunakan sebagai media pembelajaran.

Berdasarkan uji kelayakan media pembelajaran yang terdiri dari validasi dari ahli media dan ahli materi serta uji coba produk dan ujicoba pemakaian pada siswa, secara keseluruhan diperoleh jumlah skor hasil 2288 dari skor yang diharapkan 2872 dan memperoleh persentase sebesar $\mathbf{7 9 , 6 6 \%}$ berdasarkan kategori kelayakan media "Sangat Layak", jadi dapat disimpulkan bahwa media pembelajaran berbasis video tutorial interaktif pada mata pelajaran teknik animasi 2 dimensi yang telah dikembangkan, layak untuk 
digunakan sebagai media pembelajaran untuk kelas XI Multimedia di SMK Negeri 1 Kopang.

\section{SIMPULAN}

Simpulan yang dapat diambil dari penelitian yang telah selesai dilaksanakan yakni Proses penelitian dan pengembangan media pembelajaran berbasis video tutorial interaktif pada mata pelajaran teknik animasi 2 dimensi kelas XI Multimedia di SMK Negeri 1 Kopang yaitu menemukan potensi dan masalah, pengumpulan data, desain produk, validasi desain, revisi desain dan uji coba produk. Hasil penilaian media pembelajaran oleh ahli media diperoleh pesentase sebesar 86,69\%, dalam kategori kelayakan media "Sangat Layak", Hasil penilaian ahli materi sebesar $82,81 \%$, dalam kategori kelayakan media "Sangat Layak", pada hasil uji coba produk diperoleh persentase $75,93 \%$ dalam kategori kelayakan media "Layak", dan hasil uji coba pemakaian diperoleh persentase 79,89\% dalam kategori kelayakan media "Sangat Layak". Jadi berdasarkan penilaian uji kelayakan media pembelajaran berbasis video tutorial interaktif dalam mata pelajaran teknik animasi 2 dimensi yang telah dikembangkan, maka media pembelajaran sangat layak digunakan sebagai media pembelajaran dalam proses pembelajaran untuk kelas XI Multimedia di SMK Negeri 1 Kopang.

\section{REFERENSI}

Dinata, Y.N. (2013). Pengembangan Media Pembelajaran Video Tutorial Untuk Meningkatkan Hasil Belajar Siswa Teknik Gambar Bangunan SMKN 1 Seyegan Pada Mata Pelajaran Menggambar Dengan Autocad. Skripsi tidak dipublikasikan. Universitas Negeri Yogyakarta.

Efendi, A. (2014). Pengembangan Media Pembelajaran Video Tutorial Kompetensi Tune Up Sepena Motor Untuk Meningkatkan Hasil Belajar Di SMK Negeri 7 Palembang. Skripsi tidak dipublikasikan. Universitas Sriwijaya.

Fathoni, A.S. (2016). Pengembangan Media Pembelajaran Video Tutorial Pada Mata Pelajaran Sistem Operasi Kelas X Multimedia SMK Negeri 6 Surakarta Tahun Pelajaran 2015/2016. Skripsi tidak dipublikasikan. Universitas Sebelas Maret.

Pressman, R. S. (2015). Rekayasa Prangkat Lunak: Pendekatan Praktis Buku 1. Yogyakarta: Andi.

Sugiyono. (2014). Metode Penelitian Kuantitatif Kualitatif dan $R \& D$. Bandung: Alfabeta 